\title{
Assessment Implementation to Detect Children with Special Needs in Inclusive School
}

\author{
Muya Barida, Alif Muarifah \\ Department of Guidance and Counseling \\ Universitas Ahmad Dahlan \\ Yogyakarta, Indonesia \\ muya.barida@bk.uad.ac.id
}

\begin{abstract}
Assessment needs to be done to detect children with special needs appropriately. This is important for teachers to provide the right services and learning. This study aims to determine the implementation of assessment in inclusive schools. This research uses quantitative research approach with survey research method. The subject of this research is inclusive school teachers at an inclusive school. The subjects of this study were selected by simple random sampling technique. The instrument used in this study is an interview guideline. Based on the results of the interview, the data were analyzed through statistical analysis techniques. The result of the analysis shows that there is no significant difference in the assessment of inclusion schools in kindergarten, elementary, junior high, and high school.
\end{abstract}

Keywords-assessment; inclusive education; special need education

\section{INTRODUCTION}

Every human being has the right to obtain education according to the age of development and needs in his life. This is in accordance with the mandate of Law no. 20 of 2003 on the National Education System Article 5 Paragraph 1 that "every citizen has the same right to obtain quality education", followed by subparagraph 2 that "citizens with physical, emotional, intellectual and/or social impairments are entitled to obtain special education "and Verse 4 that" citizens with special intelligence and talent are entitled to special education". This mandate shows that the Government provides an opportunity for all its citizens to attend education including those with special needs or special needs children.

Children with Special Needs need special education. There is a growing form of education in order to provide special education for children with special need ranging from segregative, integrative, to inclusive [1]. These three forms of special education have different characteristics.

Segregative or segregation education forms an education system for children with special need that is separate from the normal child education system. If the normal children attend regular schools such as elementary/junior high school, junior high school, senior high school / vocational school then children with special need attend school in SLB (Special School) in accordance with the specificity of SLB-A for the blind, SLB-B for deaf, C for mentally disabled, SLB-D for physically disabled, and SLB-E for socially disabled. The form of segregation education is known as the oldest specialized education service. In addition, segregation education can have a social impact of being isolated from the general public. This statement is consistent with Morris's opinion [2] that if the child attends segregation education is called an alien, differs in a fundamental way, they never will be accepted as a full member of society.

Further integrative or integrative forms of education are the education systems in regular schools that also accommodate the children with special need by applying the same curriculum, teaching by the same teacher, the same facilities and infrastructure, and the implementation of the same teaching and learning activities. Integration education is deemed unable to meet the needs of children with special need effectively. Elton-Chalcraft [3] suggests that children with special need who attend regular schooling in the form of integration education: 1) Schools use inappropriate learning methods; 2) children with special need are not receiving adequate attention because their needs are not recognized or understood, 3) The curriculum is not suitable for children with special need, 4) children with special need is often mistreated in school, and 5) Integration education is only possible for children with special need with minor disturbance. The results of Maureen Tanyi's study [4] showed that both teachers and learners belonging to children with special need had negative attitudes in regular schools conducting integration education.

Further developed inclusive or inclusive education forms. Inclusion education is an educational system that is organized for the crew and normal children to jointly study in one roof with a decent education program, challenging, and in accordance with the abilities and needs of each learner. Biamba [5] states that inclusive education is supported by most countries and research has shown teachers' ability and success in modifying activities and contexts in several ways they can facilitate the development of children with special need. Teachers can provide facilities that support the success of children according to the type of specificity.

The above description shows that the inclusive education system is deemed most appropriate in meeting the needs of the crew. The implementation of inclusive education requires careful preparation. Ideal levels that reflect teacher readiness in inclusive schools that match the criteria of preparedness for inclusive education, among others: 1) Awareness, 
independence, and reflexivity in finding solutions for study and professional tasks, understanding and accepting inclusive education ideology, personal focus and education orientation inclusion of learners. Teachers who reach this level are highly motivated, show empathy and tolerance, 2) Recognize the values of inclusive education, 3) Have a system, integrals, comprehensive knowledge on the particularities of working with crew, 4) Deeply convinced that the crew is an extraordinary individual, 5 ) Can develop, predict, assess and describe the child's progress in inclusion education and 6) Ready to work in teams with other parents and professionals [6].

Implementation of inclusive education in inclusive schools also requires attention in the way students understand, so that teachers can plan appropriate learning according to the characteristics of children with special need. The earliest requirements are held in order to understand the learner that is the assessment. According to Gyimah and Amoako [7], inclusive education begins and ends with an assessment. Identification of the child's condition will mark the beginning of the assessment process and continue until the child's condition no longer exists. Without assessment, it will be very difficult for professionals to identify the needs of the child and provide certain services for the child.

Implementation of the assessment to detect crew at inclusive schools should be done considering that assessment results may affect the lives of children, families, and society at large. children with special need will be provided with the right service if it can be detected appropriately, and vice versa will not receive the service appropriately if not properly assessed and unable to follow the learning and finally out of school.

Mwamba,said that although efforts to make regular schools accessible and attended by a number of crew, many remain out of school. Worldwide 72 million children with disabilities out of school and $90 \%$ of children with disabilities in developing countries are not in school [8]. This also happens in Indonesia, even the assessment to detect crew is not done early. There are still many parents and teachers who do not pay attention to the importance of early detection in their learners. According to information from the Ministry of Women Empowerment and Child Protection, Lalboe that children with special needs in Indonesia as much as 532, 13 thousand inhabitants $(0.63 \%)$ of all Indonesian children. This figure is still far from the UN's assumed rate of about $10 \%$ of all school-age children having special needs, or about 4.2 million children with special needs [9].

\section{METHOD}

Subjects in this study were teachers in inclusive schools located in Yogyakarta Special Region (DIY), namely Bantul District. The sampling technique used to select the subject of the study was done by Simple random sampling [10]. Researchers randomly selected inclusive schools in DIY that became the target of the study.

Researchers collect information by conducting structured interviews [10]. The researchers collected data based on interview results to teachers in inclusive schools. The data collected in verbal form is then converted into numerical data. After the data were collected, the researcher analyzed the data with ANOVA statistical analysis technique [11]. The researchers compared the average of the organization of assessment techniques from several inclusion schools. Researchers use the help of SPSS 22.0 for Windows program to perform analysis with this analytical technique.

This research uses quantitative research approach with survey research method [10]. The researcher collects information about the experience of the teacher in conducting the assessment technique as an effort to detect the Children with Special Needs who follow the education in the inclusion school. Based on the information obtained, it can be drawn a generalizable conclusion about the assessment techniques held in the inclusion school to detect the Children with Special Needs.

Researchers carry out the research procedure through simple design [10] which includes: (1) Researchers collect information by asking a series of questions to participants or teachers in inclusive schools. The researcher collected information for about 10 minutes, (2) Summarize participants' responses by percentage, (3) Statistics calculations, and (4) Drawing conclusions about the organization of assessment techniques to detect Children with Special Needs in inclusive schools in DIY based on research subjects.

\section{RESULTS AND DISCUSSION}

Study of the assessment conducted to teachers at inclusion schools in 2 kindergarten schools, 9 elementary schools, 4 junior high schools, and 9 high school/vocational schools. The results of the answers are then analyzed and categorizated. Based on the computation that the assessment carried out in kindergarten averaged 9; elementary school is 10.8889; Junior high school ie 8.5; and senior high school is 9,5833. It can be concluded that the implementation of the assessment of Children with Special Needs in Inclusion Schools in Bantul District is less appropriate with the supposed. Furthermore, to ensure that there is a difference in the implementation of Special Need Assessment for children in inclusive schools. Based on the statistical calculation, it can be seen in the Sig column. $\mathrm{P}$ value of $\mathrm{P}$ ( $\mathrm{P}$-value) is $0,208(>0,05)$. Thus, at a significance level of 0.05 means that Ho is accepted.

It can be concluded that there is no significant difference in the assessment of Children with Special Needs either in kindergarten, elementary, junior high, or high school / vocational school. Assessment is known as an attempt to obtain information from an object. According to Loughlin \& Lewis [12] assessment is a systematic process of collecting data about individuals who function to find out the actual difficulties and needs. The systematic process involves observing, recording, classifying, and rating [13].

Djohan [14], argues that assessment is a series of analyses of individual abilities, needs and problems that must be met before the individual is given intervention. Teachers can implement the appropriate learning if the assessment carried out can accurately describe the abilities, needs, and problems of the crew. 
Assessment can illustrate the problem of an object and the function of the object [15]. This assessment is also important in collecting information about children in school. Through the assessment, it can detect the child's problem of its specificity and find the advantages that can be developed from the child. Children who have this particularity are then referred to as Children with Special Needs.

Children with special need has a special needs and shortcomings. Tanyi [16] states that children with special needs are children who demonstrate one of the several conditions that result in their need for special education and related to facilitating academic, social and emotional development. Some experts classify crew according to their characteristics.

Children with special needs are children who have a disability or a combination of disabilities that make learning or other activities difficult. Children with special need can be classified into 1) Mental retardation, which causes children to develop more slowly than other children, 2) Speech and language disorders, such as problems expressing themselves or understanding others, 3) Physical disabilities, such as vision problems, cerebral palsy, or disturbance conditions other physical, 4) learning disabilities, distorting captured messages, and 5) emotional disability, such as antisocial or other behavioral problems [17].

In line with the above description, Efendi [18] reveals the category of children with special need can be seen in terms of physical, mental, and social. Physical aspects include blind, deaf, tunawicara, and tunadaksa. The mental aspects include gifted children and tunagrahita. Social aspects include tunalaras. Blind people are abnormalities in the sense of sight or eye organs so the child can not see the objects around them. Deaf is a disorder of the sense of hearing or ear organ so that the child is completely unable to hear or hear a little sound around him. Tunawicara is an abnormality in the pronunciation utility so the child can not produce words. Tunadaksa is the inability of children to move because they do not have one of the organ of motion, such as hands. Mental retardation is a state that shows mental intelligence below normal. Tunalaras is a child's inability to adjust social behavior so that it is not adaptive.

Handojo[19] added the heaviest and most frequent types of children with special need: infantile autism, Asperger syndrome, attention deficit (hyperactive) disorder or AD $(\mathrm{H})$ $\mathrm{D}$, speech delay, dyslexia, and dyspraxia. Autism infant is a disorder in children who seem to have their own life. Asperger syndrome refers to abnormalities such as infantile autism, ie the child has difficulty in social interaction but is quite good at communicating. Gelfand \& Drew [20] argue that Asperger syndrome disorder is characterized by severe interference in social interactions accompanied by the appearance of distinctive patterns of behavior and activity. AD $(\mathrm{H}) \mathrm{D}$ is an abnormality in overactive motor behavior and impaired concentration of mind or concentration. Speech delay is the child's delay in producing words. Dyslexia is a disorder of language development. Dyspraxia is a disorder in the coordination of movement.
The Directorate of Special School Development and the Directorate General of Primary and Secondary Education Management of the Ministry of National Education [21] have also categorized the types of children with special need, including blind, deaf, al-downed, mild tunagrahita (IQ $=50$ 70) $(\mathrm{IQ}=25-50)$, severe tunagrahita (IQ under 25), talented or potential special talents (multiple intelligences: language, logic mathematics, visual-spatial, bodily-kinesthetic, musical, interpersonal, intrapersonal, natural, spiritual) , learning difficulties (al hyperactive, ADD / ADHD, dyslexia or reading disorder, dysgraphia or writing disorder, dyscalculia or computed disorders, dysphasia or speech impairment, dyspraxia or motor disorders), slow learning (IQ = 70-90), autism, drug abuse, and indigo

Meynert [22] argues that theoretically inclusion is a philosophy that emphasizes the importance of bringing together learners, families, educators and community members in order to create schools and other social institutions based on respect, acceptance, and belongingness. Inclusion as a professional thinking characteristic of the teacher determines the method or mechanism of the solution of pedagogical problems with regard to the need for education of each child, individual ability and predictable life prospects [23].

The Indonesian government has provided the opportunity for qualified schools to program their schools into inclusive schools. The school of inclusion is a place of learning that organizes educational practices for children with disabilities and children without disabilities or normal children [24]. In line with this statement, Valeeva \& Kulesza[25] suggests that inclusive schools provide education for learners with disabilities and learners with successful developments simultaneously. In inclusive schools, the crew can mingle with normal children without the loss of need fulfillment facilitated by the school.

Chatib \& Said[26] further argues that inclusion schools are regular schools where normal children learn in which there are also children with special need. There is no fundamental difference in the treatment of teachers to learners, which distinguishes only the ways in which the teacher meets the needs of the learners according to their specificity. Lina [27] stated that inclusive schools are schools that implement inclusion system, which includes all children both regular and special needs into one education system. The curriculum in the inclusion school is tailored in such a way that regular learners and learners who are classified as children with special need can follow the same lesson. The advantages of inclusion schools one of which is students learners become accustomed to appreciate diversity and increase tolerance among friends of different abilities.

The purpose of the inclusion school is not just to include the crew into regular or normal classes, but to help all children develop their potential[28]. In addition, inclusive schools focus not only on the needs of disabled learners but to instill the meaning of differences and similarities in a better context[29]. The community will be familiar with the existence of children with special need starting from the existence of inclusive schools. 
Gallagher and Bennet [30] point out the advantages of inclusion schools that are categorized into four areas: attitudes and beliefs about inclusion, supporting placement / fostering self-reliance, work competence, and workplace dynamics. Implementing an inclusive school can improve the positive attitudes and beliefs that all children have the right to grow, every child has the advantage of being able to live independently, improving the competence so that it can perform the work of its excess, and create a dynamic within the working environment between the crew and the normal child.

Sarasvati and Sumardianti [5] proposed to establish an inclusive school that aims to accommodate the crew, the school must understand the needs of students and must be ready to meet the needs of learners. Efforts to understand these learners were initially undertaken through assessment. Implementation of the assessment should be through collaboration between the parties who understand the child's growth stage. Morgan,mentions the need for collaboration because it is effective in order to improve learning outcomes for all learners residing in inclusive schools. Collaboration built in conducting diagnosis, planning, teaching, and assessment of learners with disabilities [31]. Collaboration between schools involves experts who understand children's growth and education.

Assessment is essential to provide appropriate interventions so that teachers are able to develop the potential of children with special need. The earliest assessment was conducted to determine the presence of a disability in the child and why the disability occurred. This process is critical to the successful development of an intervention plan. Benner \& Grim exemplifies when a hyperactive child is aggressively non-verbal whose appearance is similar to that of a child with the total hearing loss. If the assessment is not accurately assessed, then the intervention plan may be different. Therefore the assessment to detect crew at inclusion schools is highly emphasized. Ferns and Zegwaard [32] also argue that often the assessment has been carried out but not optimal in providing feedback and informing the progress or development of the crew in the future. Therefore the implementation of the assessment should be done carefully, thoroughly, and appropriately.

Assessment is performed to detect children who exhibit special needs characteristics. Assessment is particularly important for meeting CRK needs appropriately in the classroom learning process [33]. Through the implementation of the assessment, teachers can also minimize the existence of trial and error in providing learning for students who are classified as children with special need.

Mensah and Shayar [34] state that assessment needs to be done by professionals or through an interdisciplinary approach so that an Individualized Educational Program (Individual Learning Program) is established to meet the overall needs of the child. Assessments to detect risk factors for the child's disabilities that lead to the children with special need category are essential. Where no assessment or lack of collaboration in the assessment procedure will adversely affect the cognitive, social or behavioral achievement of the child.
Assessments are used as a basis for providing learning or special services for children with special need. The National Research Council [35] conveys the importance of teachers' ability to detect early signs of children with special need so as to be advantageous in early intervention. In addition, teachers can also determine approaches that are specifically effective for children. Parties related to the child can prepare themselves to provide everything that can help the child to grow according to his abilities.

\section{CONCLUSION}

The results of the research activities can be concluded that the work experience and educational background have no significant effect on the performance of counselors in organizing individual counseling services in schools. Professionalization should be done by all counseling teachers or counselors or counselors in schools either who have long worked as school counselors or who are still referred to as new guidance and counseling teachers or counselors. Teachers with no undergraduate background Guidance and Counseling also study a range of skills in organizing individual counseling in schools.

Based on the results of the assessment analysis to detect the Children with Special Needs in inclusive schools, it can be concluded that the implementation of the assessment in kindergarten, elementary, junior high, and high school / vocational school less appropriate. Furthermore, it is followed by the mean difference test that either in kindergarten, elementary, junior high school, or high school / vocational school have the same relative average value. This means that in inclusive schools are still less appropriate in the assessment implementation to detect Children with Special Needs.

Implementation of effective inclusive education requires accountable preparation of one of them in conducting student assessments that are likely to be classified as Children with Special Needs. Supposedly, the Assessment of Special Needs Children is carried out by all schools so that the services and learning undertaken by teachers are appropriate to the needs of the students, with standard assessment techniques and have adequate knowledge of the types of assessment techniques, as well as clear and systematic assessment procedures.

\section{REFERENCES}

[1] S. A. Kirk, "Pendidikan Anak Luar Biasa.” DNIKS: Jakarta, 1989

[2] M. Gil, "From Segregation to Equalization: The Polish Perspective," J. Contemp. Issues Educ., vol. 2, no. 1, 2007.

[3] S. Elton-Chalcraft, P. Cammack, and L. Harrison, "Segregation, integration, inclusion and effective provision: a case study of perspectives from special educational needs children, parents and teachers in Bangalore, India," Int. J. Spec. Educ., vol. 31, no. 1, pp. 29, 2016.

[4] M. E. Tanyi, "Pedagogic Barriers in Cameroon Inclusive Classrooms: The Impact of Curriculum, Teachers' Attitudes and Classroom Infrastructures.," J. Educ. Pract., vol. 7, no. 18, pp. 210-221, 2016.

[5] C. Biamba, "Inclusion and Classroom Practices in a Swedish School: A Case Study of a School in Stockholm.," J. Educ. Pract., vol. 7, no. 3, pp. 119-124, 2016

[6] Z. A. Movkebayeva, I. A. Oralkanova, B. M. Mazhinov, A. B. 
Beisenova, and O. G. Belenko, "Model of Formation for Readiness to Work within Inclusive Education in Teachers.," Int. J. Environ. Sci. Educ., vol. 11, no. 11, pp. 4680-4689, 2016.

[7] E. K. Gyimah and R. Amoako, "Pre-Service Teachers' Perceptions on Procedures to Identify and Assess Children with Special Educational Needs and Disabilities: The Case of Tutors of Colleges of Education in Ghana.," J. Educ. Pract., vol. 7, no. 21, pp. 110-116, 2016.

[8] M. N. Mwamba, "Provision and Management of Special Education in Community Schools: A Case of Donata, Malaikha and Shalom Community Schools in Zambia.," Int. J. Spec. Educ., vol. 31, no. 1, pp. 97-103, 2016.

[9] M. Asif and A. Raouf, "Setting the course for quality assurance in higher education," Qual. Quant., vol. 47, no. 4, pp. 2009-2024, 2013.

[10] P. D. Leedy and J. E. Ormrod, Practical research: Planning and design. Pearson Education, 2014.

[11] S. Siregar, "Statistika terapan untuk perguruan tinggi," Jakarta Prenadamedia Gr., 2015.

[12] S. Cervai, L. Cian, A. Berlanga, M. Borelli, and T. Kekäle, "Assessing the quality of the learning outcome in vocational education: the Expero model," J. Work. Learn., vol. 25, no. 3, pp. 198-210, 2013.

[13] S. F. Prihadi, "Assessment Centre Identifikasi, Pengukuran, dan Pengembangan Kompetensi," Jakarta PT Gramedia Pustaka Utama, 2004.

[14] D. Salim, "Terapi Musik Teori dan Aplikasi." Yogyakarta: Galang Press, 2006.

[15] S. R. Smith and L. Handler, The clinical assessment of children and adolescents: A practitioner's handbook. Routledge, 2014

[16] M. E. Tanyi, "Psychological Evaluation of Attitudes of Both Primary Teachers and Special Needs Children towards Each Other in a Regular School in Yaoundé-Cameroon.," J. Educ. Pract., vol. 7, no. 6, pp. 6373, 2016

[17] P. Golding and V. Tennant, "Servicing the learning needs of the deaf community: an action design research approach," in Proceedings of the AIS SIG-ED IAIM 2013 Conference, 2013.

[18] M. Efendi, "Pengantar psikopedagogik anak berkelainan." Jakarta: Bumi Aksara, 2006.

[19] Y. Handojo, “Autisma,” PT Buana Ilmu Pop. Kelompok Gramedia Jakarta, 2003

[20] D. M. Gelfand, W. R. Jenson, and C. J. Drew, Understanding child behavior disorders. Harcourt College Pub, 1997.

[21] D. P. Nasional, "Direktorat Jenderal Pendidikan Dasar dan Menengah Direktorat Pendidikan Menengah Kejuruan.” Jakarta, 2004.

[22] M. J. Meynert, "Inclusive Education-Perceptions of Learning Facilitators of Children With Special Needs (Inkluderande utbildninguppfattningar av specialpedagoger som underlättar lärandet för elever med särskilda behov)," 2012.

[23] G. F. Biktagirova and V. V Khitryuk, "Formation of future pre-school teachers' readiness to work in the conditions of educational inclusion," 2016.

[24] E. V Zvoleyko, S. A. Kalashnikova, and T. K. Klimenko, "Socialization of Students with Disabilities in an Inclusive Educational Environment.," Int. J. Environ. Sci. Educ., vol. 11, no. 14, pp. 64696481, 2016.

[25] R. A. Valeeva and E. M. Kulesza, "Education for Persons with Special Needs: Polish and Russian Experience.," Int. J. Environ. Sci. Educ., vol. 11, no. 7, pp. 1619-1629, 2016.

[26] M. Chatib, Sekolah anak-anak juara: berbasis kecerdasan jamak dan pendidikan berkeadilan. Kaifa, 2012.

27] R. D. Lina, HEMAT 'BISA'MISKIN, BOROS 'PASTI'KAYA! Penebar PLUS+, 2014

[28] S. Setyawati, "EFEKTIVITAS PROGRAM KARTU INDONESIA PINTAR (KIP) BAGI SISWA SMK DI KECAMATAN JERUKLEGI KABUPATEN CILACAP (STUDI PERMENDIKBUD NO. 12 TAHUN 2015 TENTANG PROGRAM INDONESIA PINTAR)." IAIN Purwokerto, 2018.

[29] S. Carrington, "Inclusion needs a different school culture," Int. J. Incl. Educ., vol. 3, no. 3, pp. 257-268, 1999.
[30] T. L. Gallagher and S. M. Bennett, "School Supported Work Placements for Students with Intellectual Disabilities: Why Inclusive Principles/Principals Matter!.," Int. J. Leadersh. Learn., vol. 1, no. 1, p. n1, 2013.

[31] N. M. Anati and A. Ain, "Including Students with Disabilities in UAE Schools: A Descriptive Study.," Int. J. Spec. Educ., vol. 27, no. 2, pp. 75-85, 2012.

[32] S. Ferns and K. E. Zegwaard, "Critical assessment issues in workintegrated learning," 2014.

[33] S. Akalin, S. Demir, B. Sucuoglu, H. Bakkaloglu, and F. Iscen, "The Needs of Inclusive Preschool Teachers about Inclusive Practices.," Eurasian J. Educ. Res., vol. 54, pp. 39-60, 2014.

[34] F. A. Mensah and J. Badu-Shayar, "Identification of Special Educational Needs for Early Childhood Inclusive Education in Ghana.," J. Educ. Pract., vol. 7, no. 11, pp. 1-8, 2016.

[35] M. Mereoiu, C. Bland, N. Dobbins, and J. A. Niemeyer, "Exploring Perspectives on Child Care with Families of Children with Autism.," Early Child. Res. Pract., vol. 17, no. 1, p. n1, 2015. 